\title{
PALEOCLIMATIC SIGNIFICANCE OF MICROFLORA RETRIEVED FROM WELL ' $Y$ ', WESTERN NIGER DELTA, NIGERIA
}

SAKA ADELAYO OPELOYE AND IFEOLUWADUN O. ADELABU

(Received 21 July 2015; Revision Accepted 30 October 2015)

\begin{abstract}
Palynomorph species comprising 53 pollen, 7 spores, 2 algae and 6 dinoflagellate cysts were recovered from a section of well ' $Y$ ' located in the offshore western Niger Delta and were used for paleoclimatic deductions of the sediments. There was a dominance of the fresh water swamp species over the brackish, savannah and the rain forest types. Stratigraphically, four floral zones corresponding to inferred climatic units were identified. M2 floral zone, at the lower portion of the well, occurred between $8150 \mathrm{ft}(2486 \mathrm{~m})$ and $6440 \mathrm{ft}(2147 \mathrm{~m})$. It corresponded to wet and humid climate with periodic rainfall. M1 floral zone was between $6440 \mathrm{ft}(1964 \mathrm{~m})$ and4820 ft $(1470 \mathrm{~m})$ indicating a dry climatic phase in a high sea level stand. The P7 floral zone was also a humid climate in a sea level rising environment while the topmost floral zone between $4370 \mathrm{ft}(1333 \mathrm{~m})$ and3125 ft $(953 \mathrm{~m})$ was a fluctuating dry and wet climatic phase in a tidally influenced environment. A humid tropical climate characterised by alternation of dry and wet regimes occasioned by sea level changes and cyclic fluctuation in continental climatic condition is inferred from the analysed well that spanned through Late Miocene and Early Pliocene.
\end{abstract}

KEYWORDS: Floral zones; Niger Delta; Paleoclimate; Palynomorphs; spores; pollen

\section{INTRODUCTION}

Deltaic facies, typified by Niger Delta environment, have abundant palynomorphs whose occurrence does not only reflect variations of sediment provenance but also the environmental conditions that supported the floral growth. The abundance therefore readily becomes a tool for paleoclimatic interpretation as the various morphophyte groups do reflect different vegetational species consequent upon climatic differences (Sowunmi, 1987 and Ivanor et al., 2007). In Nigeria, palynological studies had largely been conducted on the Tertiary Niger Delta on account of increasing exploratory activities resulting from the discovery of petroleum resources in the late 1950s. Most of these reports are, however, under the proprietary control of the oil and gas prospecting companies. The few published papers are those of Jan du Chêne et al. (1978), Sowunmi (1981), Odebode and Salami (1984) as well as Lawal and Moullade (1986). The present study presents identified palynomorphs retrieved from well " $Y$ " owned by Chevron Nigeria Limited in the western offshore of Niger Delta (Fig. 1). The palynomorphs enable paleoclimatic deductions for the floral environment.

Saka Adelayo Opeloye, Department of Applied Geology, Federal University of Technology, Akure, Nigeria.

Ifeoluwadun O. Adelabu, Department of Applied Geology, Federal University of Technology, Akure, Nigeria. 


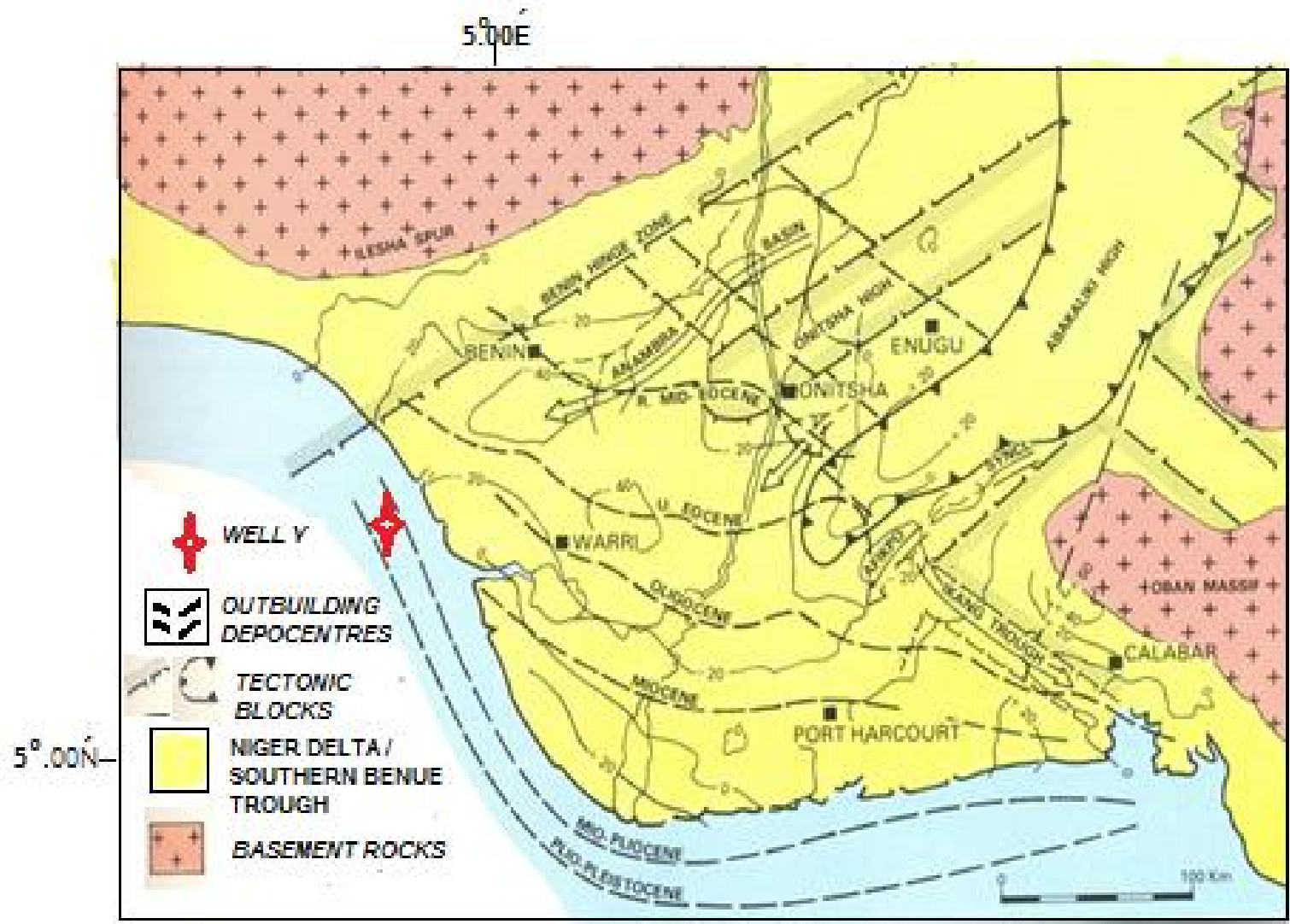

Fig.1: Location of Well ' $Y$ ' in the offshore of western Niger Delta Oil Province (Modified after Whiteman 1982)

\section{METHOD OF STUDY}

Ditch cutting samples from well ' $Y$ ' retrieved from the Niger Delta Basin were made available by Chevron Nigeria Ltd for this study. The sampling intervals ranged from $3125 \mathrm{ft}(953 \mathrm{~m})$ to $8150 \mathrm{ft}(2486 \mathrm{~m})$. The samples were composited at $90 \mathrm{ft}(27.45 \mathrm{~m})$, making a total number of 56 samples for the palynological analysis. Standard techniques involving treatments with $\mathrm{HCl}(10 \%)$ and $\mathrm{HF} \mathrm{(60 \% )} \mathrm{were} \mathrm{applied.} 25 \mathrm{~g}$ by weight of each of the samples were treated with $\mathrm{HCl}, \mathrm{HF}, \mathrm{NH}_{4} \mathrm{OH}$ (5\%) and $\mathrm{ZnBr}_{2}$ for the purpose of removing carbonates, silica/silicates, nitrates and mineral matters respectively.

The recovered organic matter were uniformly spotted on arranged cover slips of $22 / 32 \mathrm{~mm}$ size, and then allowed to dry in sunlight, before being mounted on properly labelled slides. The mounting medium used was the glycerine oil. The cover slips were gently lowered to the slides, so as to prevent air bubbles.

The prepared palynological slides were studied under the transmitted light microscope made by Olympus Corporation; model CHB $213^{(R)}$. Sometimes staining with immersion oil was necessary in order to enhance the visibility of transparent palynomorphs. Palynomorphs were identified, described and counted for as many forms as possible. Relevant literatures were used in their identification like Legoux, 1978; Evamy et al., 1978; Morley, 1995 etc. Some pictures of the palynomorphs were taken using a special camera attached to the microscope, the DP $12^{(R)}$ Olympus camera.

\section{RESULTS AND DISCUSSION}

A total number of seventy palynomorphs, comprising fifty-three pollen, seven spores, two algae, six dinoflagellates and two fungi sporeswere counted after screening. The abundant forms among the pollen were terrigenous species and comprise Zonocostites ramonae, Monoporites annulatus, Sapotaceoidaepollenites (Sapotacea) spp, Retibrevitricolporites protrudens, Retitricolporites irregularis and Cyperaceapollis sp. The prominent spores were Laevigatosporites spp and Acrostichum aureum. The Dinocysts were represented by Spiniferites spp, polysphaeridium zoharyi, Lingulodinium machaerophorum, Operculodinium centhrocarpum and Leiospheridium spp while the algae were Botryococcus braunii with a few Pediastrum sp .Some of the retrieved forms are shown in Fig. 2. 

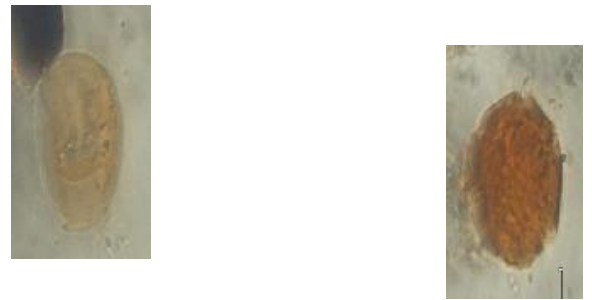

Monoporites

annulatus Pachydermites
diederixi

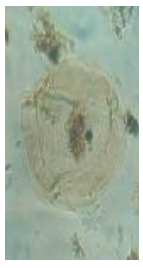

Nympheaepollis clarus

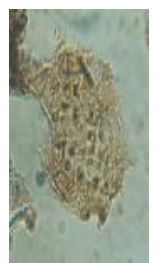

Verrucatosporite

$s \mathrm{sp}$

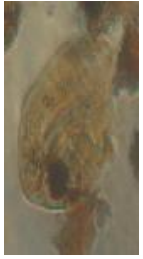

Gemmamonoporites

sp.

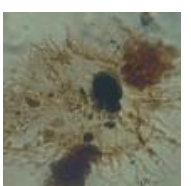

Spiniferites ramosus

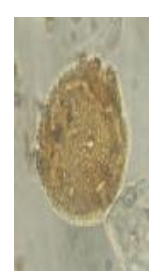

Retibrevitricolpo

rites

protrudens

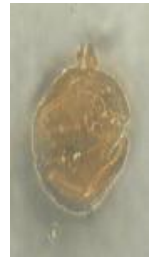

Sapotacea

sp.

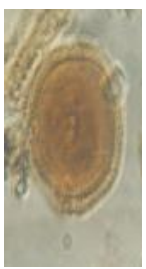

Numulipollis neogenicus

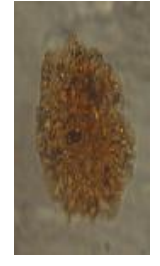

Botryococcusbrau nii

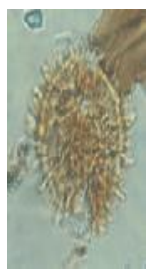

Retitricolporitesirregularis

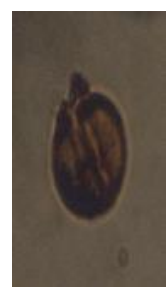

Zonocostitesramonae

Fig. 2: Some of the retrieved palynomorphs (magnification-x 800) from well'Y', western Niger Delta

\section{Microflora Paleoecology}

Using Rao (2001) and Rull (2003) ecological group classifications, four major groups comprising fresh-water swamp, brackish-water swamp, savannah, rain forest species and other indeterminate forms constitute the microflora of the studied section (Fig. 3) 


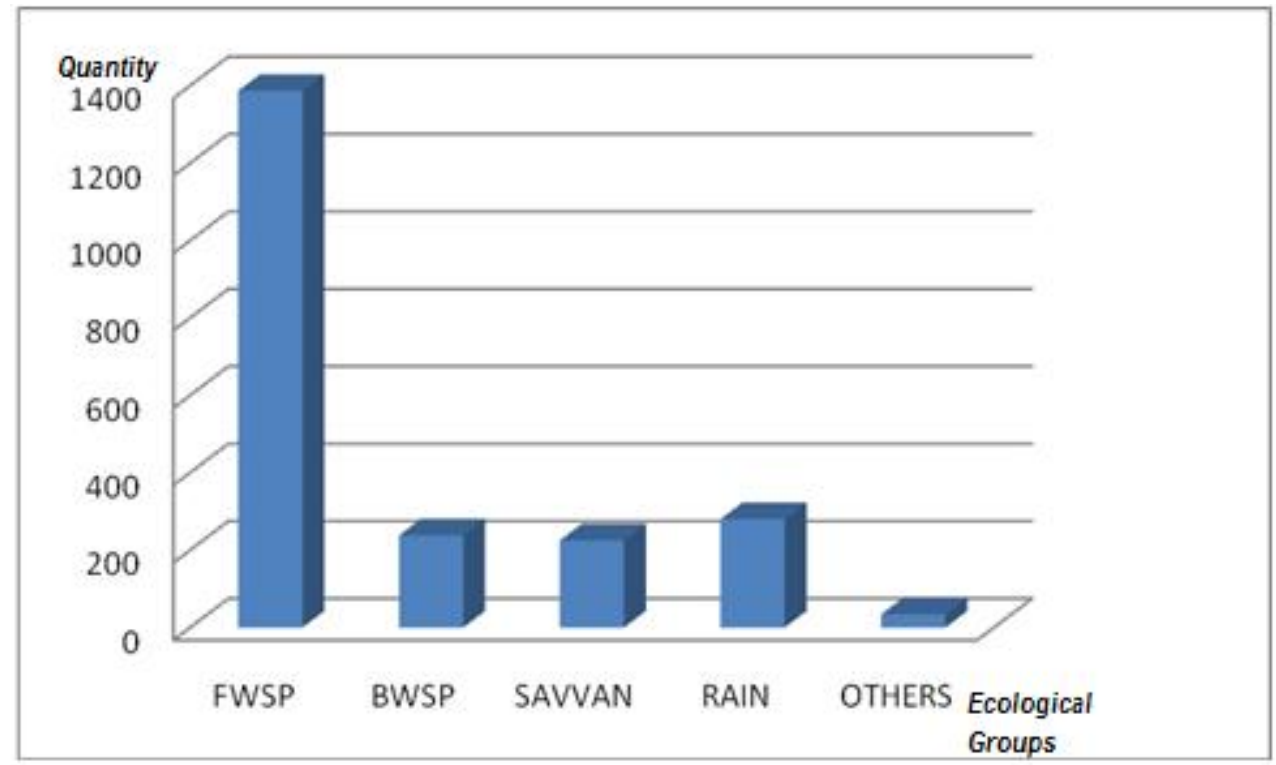

FWSP = Fresh water swamp species; BWSP = Brackish water swamp species;SAVVAN = Savannah species; RAIN = Rain Forest species; OTHERS= Indeterminate species

Fig. 3: Relative Quantities of the Identified Forms Depicting the Ecological Group Abundance

\begin{abstract}
Abundance.
The Fresh water swamp species group dominates the assemblage with forms mainly made up of Zonocostites ramonae. Others are Retitricolporites irregularis, Retibrevitricolporites protudens, Magnastriatites howardii, Psilatricolporites operculatus while the dominant forms of brackish water swamp species include Psilatricolporites crassus and Pachydermites diederixi. Four 'Floral' zones are established from the entire assemblage based upon the phytoecological groupings and paleoenvironmentally significant species. They are the M2 and M1 of the Late Miocene and the P7 and P6 of the Early Pliocene
\end{abstract}

\section{'Floral' zone M2}

The zone ranges from 8150 to $6440 \mathrm{ft}$ corresponding to2486 to1964 m.

The basal depth $(8150 \mathrm{ft} / 2486 \mathrm{~m})$ of the studied interval marks the beginning of zone M2. The grass pollen, Monoporites annulatusis almost nonexistent but there is an observed increase in Zonocostites ramonae up to a depth of 6530ft $(1992 \mathrm{~m})$ where a maximum count of 270 is picked. The consistency in the record of this mangrove pollen together with fresh water swamp/rain forest species of Sapotaceae sp., Retibrevitricolporites protudens, Gemmamonoporites spp., Striatricolpites catatumbus and Botryococcus braunii is an indication of preponderance of a wet climate. There is also a rare occurrence of marine elements, dinocysts Polysphaeridium zoharyi and acritarch Leiosphaeridia spp., as well as savannah pollens, Concentricytis spp., Elaeis guineensis, Cyperaceaepollis spp., Pteris spp., Ctenolophonidites costatus. The zone probably experienced a tropical humid climate with periodic rainfall during this time. The presence of the dinocysts species, Polysphaeridium zoharyi, known for its adaptation to very saline waters, and the acritarch Leiospaeridia spp. along with freshwater algae Botryococcus braunii, also suggests sediment deposition in shallow marine environment with frequent freshwater incursions.

\section{'Floral' zone M1}

The zone ranges from 6440 to $4820 \mathrm{ft}$ corresponding to 1964 to $1470 \mathrm{~m}$.

There is a sharp quantitative (numerical) drop of mangrove pollen, Zonocostites ramonae from 270 counts at $6530 \mathrm{ft}(1992 \mathrm{~m})$ to 33 counts at $6350 \mathrm{ft}(1937 \mathrm{~m})$ and 26 counts at $5900 \mathrm{ft}(1800 \mathrm{~m})$, but with a gentle downhole increase in Monoporites annulatus within this zone. The Dinocysts diversity also peaked within this zone (at $6170 \mathrm{ft} / 1882 \mathrm{~m}$ ), with no record of fresh water species Botryococcus braunii. Generally the zone seems to have records of species adapted to very saline and warm water forms like Polysphaeridium zoharyi and Operculodinium centrocarpum respectively. Marine species Lingulodinium machaerophorum is also restricted to this zone. There are also noticeable fluctuations in the occurrence of ferns, Laevigatosporites spp., Verrucatosporites spp., and Stereiosporites spp. The absence of Botryocoocus braunii at $6170 \mathrm{ft}(1882 \mathrm{~m})$ strongly suggests a $100 \%$ marine environment. Nevertheless, important few savannah and rain forest/fresh water swamp species also occur within the zone. The savannah species include Concentricytis spp., Proteacidites spp., Cyperaceaepollis spp., Corylus spp., Pteris spp., Chenophodipollis spp while the rainforest/fresh water swamp species include Canthium spp., Brevitricolporites guinetii, Psilatricolporites operculatus. This zone is probably a marine prone area having a dry climatic phase with warm temperatures at times of lowered sea levels and low fluvial activity.

\section{Floral' zone P7}

The zone ranges from 4820 to $4370 \mathrm{ft}$ corresponding to 1470 to $1333 \mathrm{~m}$.

Within this depth slice, a relatively low percentage composition of Monoporites annulatus predominates with the ratio of Monoporites annulatus to Zonocostites ramonae ranging from 0.40 to 3.40 . Conversely, abundant quantities of mangrove pollen, Zonocostites ramonae, are recorded with common to abundant fresh water algae, Botryococcus braunii. Also 
noticeable is an increase in brackish water swamp species, Pachydermites diederixi and Psilatricolporites crassus. Large representation of fern spores was also a major feature in this zone. The only record of Palmae pollen, Retitricolpites spp. is at $4370 \mathrm{ft}$ (1333) $\mathrm{m}$. Some of the fresh water swamp species that characterize the zone includes Sapotaceae sp, Retitricolporites irregularis, Gemmamonoporites spp., Retibrevitricolporites protudens and Acrostichum aureum. The pollen record indicates a rise in sea level and an extension of mangrove swamps.

\section{'Floral' zone P6}

The zone ranges from 4370 to $3125 \mathrm{ft}$ corresponding to 1333 to $953 \mathrm{~m}$.

In this zone, the pollen record indicates that mangrove swamp forest vegetation is now well established, with the quantitative occurrence of Zonocostites ramonae reaching its highest numerical value. So also is the high occurrence of fresh water swamp species, Sapotaceae, Retitricolporites irregularis and Retibrevitricolporites protudens. There is, however, a rare occurrences of other fresh water sporomorphs of Verrutricolporites rotundiporus, Gemmamonoporites spp., Rauwolfia vomitoria, Verrutricolporites microporus, Marginipollis concinnus including fresh water algae, Botryococcus braunii. There is also a rare to common occurrences of the brackish water swamp species of Pachydermites diederixi and Psilatricolporites crassus. Within the zonal interval it is worthy to note the increase in abundance of pteridophytes (fern spores), Laevigatosporites spp., Verrucatosporites spp. and Stereiosporites spp. coupled with an almost consistent occurrence of Acrostichum aureum but rare occurrences of lowland rainforest species of Nympheaepollis clarus, Echistephanoporites echinatus, Racemonocolpites hians, Bombacacidites bellus, Canthium spp. There is also an overall increase in the recorded quantities of grass pollen, Monoporites annulatus, comparable numerically to mangrove pollen. This is in tandem with a visible common to abundant occurrences of Corylus spp., Cyperaceaepollis spp. and Pteris spp., and rare to common occurrences of Ctenolophondites costatus,
Chenophondipollis spp., Numulipollis neogenicus, Peregrinipollis nigericus, including charred gramineae cuticle, which are all savannah species and are indicative of a dry climate. An initial rise in sea level with increasing expanse of mangrove vegetation is interpreted followed by a probable alternation of dry and wet climates in this zone.

\section{Paleoclimatic Implication}

A wet condition is suggested for the studied section of the well between $8150 \mathrm{ft}(2486 \mathrm{~m})$ and $6440 \mathrm{ft}$ (195 $\mathrm{m}$ ) on account of the regular occurrence of mangrove pollen, abundant fresh water algae and brackish water swamp species. However remarkable increase in the Gramineae pollen and a rare record of humid climatic indicator, Cyperraceaepollis spp., allow the interpretation of a tropical humid climate with irregular rainfall. Mozardec-Kerfourn (1992) while working on the deep sea sediments of the West African margin attributed the dominance of Operculodinium centrocarpum and Polysphaeridium zoharyi to lowered sea levels following glacial maxima. In another consideration, Udeze and Oboh-Ikuenobe (2005) linked Operculodinium centrocarpum observed among palynological data from Cape Basin of South Africa to warm climate. With the flourishing of mangrove and fresh water forms in this unit, it is therefore inferred that sediment deposition is in a shallow marine environment with frequent freshwater incursions.

The unit between depth slice $6440 \mathrm{ft}(1964 \mathrm{~m})$ and $4820 \mathrm{ft}(1470 \mathrm{~m})$ is a dry climatic phase with warm temperatures as indicated with the increase in the quantities of Monoporites annulatus. Vermoere et al. (1999) in a study in SW Turkey reported that high percentages of Gramineae pollen types in sediment points to drier local conditions. There was a noticeable presence of savannah species Echitricolporites spinosus, which further confirms the prevalence of a dry climate. Other important savanna species occurring within this zone include Concentricytis spp., Proteacidites spp., Cyperaceaepollis spp., Corylus spp., Pteris spp., Chenophodipollis spp., and more. However, a few rainforest/fresh water swamp species 


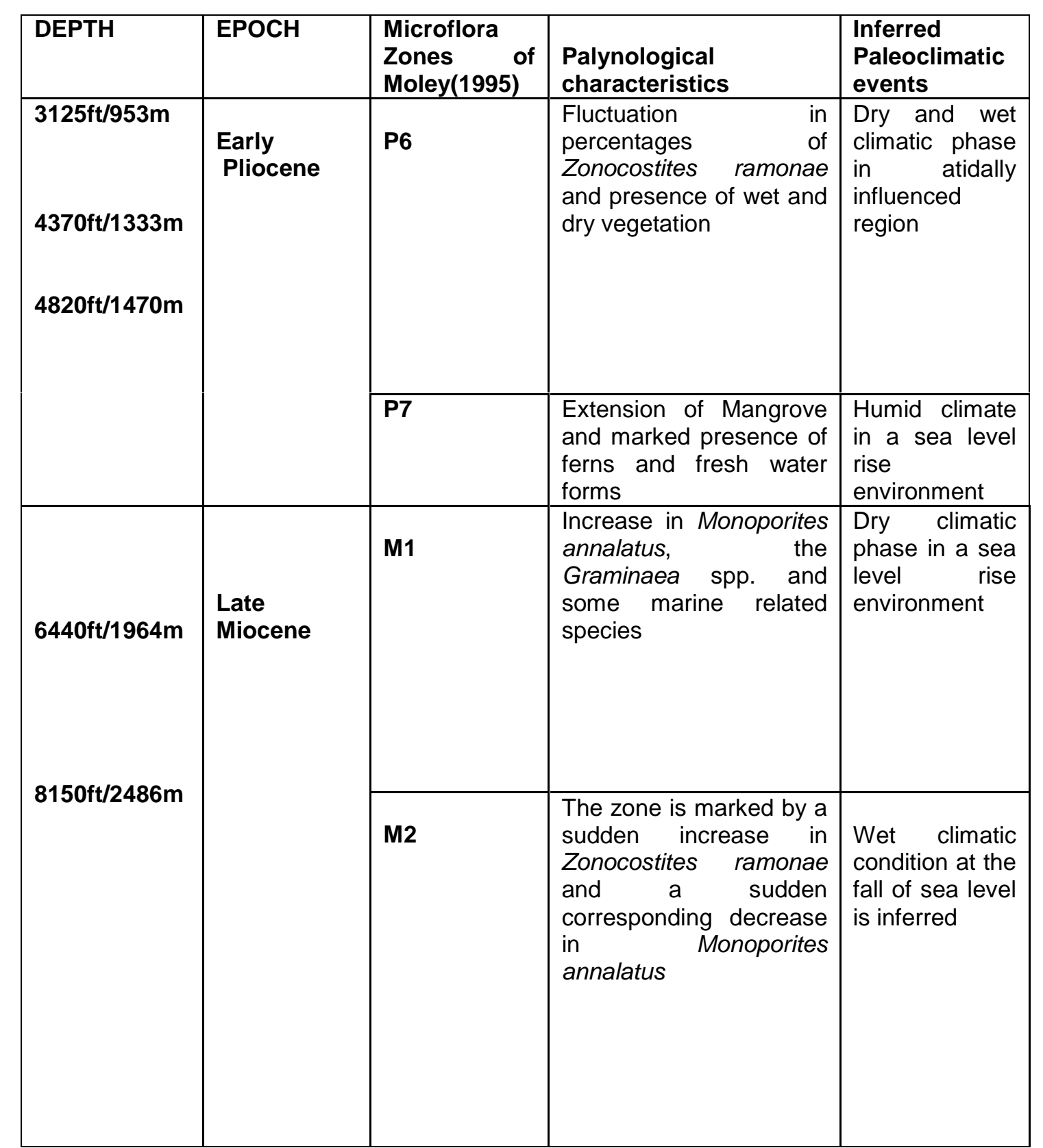

Fig. 4: Recognised Microfloral zones in well ' $Y$ ' with palynological and inferred paleoclimatic events

are recorded which includes Canthium spp., Brevitricolporites guinetii, Psilatricolporites operculatus and a rare to common record of Botryococcus braunii. Occurrence of small quantities of mangrove pollen in this zone is probably due to minor local short-lived transgressions of the sea.

The pollen record within depth slice $4820 \mathrm{ft}(250$ $\mathrm{m})$ and $4370 \mathrm{ft}(1333 \mathrm{~m})$ indicates a rise in sea level and an extension of mangrove swamps. It has been reported that high values of Zonocostites ramonae characterize periods with a high sea level (Lezine and VergnaudGrazzini, 1993; Crowley and Gagan, 1995). The preponderance of ferns and occurrence of Cyperaceae in this zone coupled with the presence of fresh water swamp forest species indicate a dominance of wet and humid conditions that supported ample vegetation. Nevertheless, a substantial occurrence of Gramineae pollen, Monoporites annulatus and a few savannah species like Corylus spp. indicates fluctuation in environmental conditions as the sea level rose.
The topmost unit of the investigated section between depth $4370 \mathrm{ft}(1333 \mathrm{~m})$ and $3125 \mathrm{ft}(953 \mathrm{~m})$ give an indication of increasing mangrove vegetation as the sea level continued to rise. However tidal influence is inferred on account of the fluctuations in percentage occurrence of Zonocostites ramonae. The rise and fall of tides are capable of bringing about drier conditions resulting in a reduction of forest vegetation and subsequently promoting extension of the savannah. This agrees with the reports of Leroy and Dupont (1994) establishing cyclic fluctuations in the vegetation and continental climatic conditions of NW Africa in the Pliocene.

\section{CONCLUSION}

Palynomorphs recovered from well ' $Y$ 'located in the western offshore of Niger Delta provide large quantities of pollen and spores as well as some quantities of algae and dinocysts. The forms are 
classified into ecologic groups of fresh water swamp, brackish, savannah and rain water species. Stratigraphically, four floral zones on the basis of phytoecological assemblage are recognised from the investigated section of the well. The four floral zones correspond to the M2, M1, P7 and P6 of the Microfloral zones of Morley (1995) with paleoclimatic significance. M2 zone is characterised by sudden increase in Zonocostites ramonae and decrease in Monoporites annulatus. It is between $8150 \mathrm{ft}(2486 \mathrm{~m})$ and $6440 \mathrm{ft}$ $(1964 \mathrm{~m})$ of the section of the investigated well. Wet humid climatic condition at the fall of sea level is interpreted. M1 zone is marked by increase in Monoporites annalatus and some marine related species. It is within 6440 (1964 m) and $4820 \mathrm{ft}(1470 \mathrm{~m})$ of the well. It represents a transgressive deposit within a dry climatic phase. P7 is between $4820 \mathrm{ft}(1470 \mathrm{~m})$ and $4370 \mathrm{ft}(1333 \mathrm{~m})$ of the well. It represents a humid climate marked by fluctuating atmospheric condition and transgressive deposits that supports extension of mangrove swamp. The upper portion of the well, between $4370 \mathrm{ft}(1333 \mathrm{~m})$ and $3125 \mathrm{ft}(953 \mathrm{~m})$, falls within the P6 unit of Morley (1995). The unit is characterised by tidally influenced regime which promoted dry and wet climatic phases (Fig. 4).

A humid tropical climate characterised by alternation of dry and wet regimes occasioned by sea level changes and cyclic fluctuation in continental climatic condition is inferred from the analysed well. River Niger catchment being along the corridors of mangrove and forest region might be responsible for the persistence in the occurrence of mangrove and rain forest pollen Zonocostites ramonae and Retitricolporites irregularis, Canthium spp. throughout the stratigraphic column of the well.

\section{REFERENCES}

Crowley, G. M and Gagan, M. K., 1995. Holocene evolution of coastal wetlands in wet-tropical Northeastern Australia. Holocene, 5: 385-399.

Evamy, B. D., Herembourne, J., Kameling, P., Knaap, W. A., Molly, F. A and Rowlands, P. H., 1978. Hydrocarbon habitat of Tertiary Niger-Delta. American Association of Petroleum geologist. Bulletin, 62, 1-39.

Ivanor, D. A., Ashraf, A. R and Mosbrugger, V., 2007. Late Oligocene and Miocene climate and vegetation in the eastern Paratethys area (Northeast Bulgaria), based on pollen data. Palaeogeography Palaeoclimatology and Palaeoecology, 255: 342-360.

Jan du Chene, R. E and Salami, M. B., 1978. Palynology and Micropaleontology of the Upper Eocene of the well Nsukwa-1 (Niger Delta, Nigeria).Compterendu des séances de la Sociétéde physique etd'histoirenaturellede Genève., 13: 5-9

Lawal, O and Moullade, M., 1986. Palynological biostratigraphy of the Cretaceous sediments in the Upper Benue Basin, N.E. Nigeria. Revista Micropaleontologia, 29, (1): 61-83.
Legoux, O., 1978. QuelquesEspeces e Pollen Caracteristiques Du Neogene Du Nigeria. Bulletin Centre De Recherches ExplorationProduction Elf-Aquitaine., 2: 265 - 317.

Leroy, S. A. G and Dupont, L., 1994. Development of vegetation and continental aridity in Northwestern Africa during the Late Pliocene: The pollen record of ODP site 658. Paleogeography Paleoecology, 109: 295-316.

Lezine, A. M and Vergnaud-Grazzini, C., 1993. Evidence of forest extension in West Africa since 22,000 BP: A pollen record from the eastern tropical Atlantic. Quaternary Science Reviews, 12: 203-21.

Morley, R. J., 1995. Biostratigraphic characterization of systems tracts in Tertiary sedimentary basins. Proceedings of the International Symposium on Sequence Stratigraphy in S.E, Asia, 49-71.

Mozardec-Kerfourn, M. T., 1992. Estuarine Dinoflagellate Cysts among Oceanic Assemblages of Pleistocene Deep-Sea Sediments from the West African Margin and their Paleonenivronental Significance. In: Neogene and QuartenaryDinoflagellate Cysts and Acritarchs, Head, M.J. and J.H. Wrenn (Eds.). American Association of Stratigraphic Palynologists Foundation, Dallas, 133-146.

Odebode, M. O and Salami, M. B., 1984. Palynology of the Odukpani Formation (Middle Cretaceous), of Southeastern Nigeria. Nigerian Journal of Science, 18, 83-94.

Rao, M. R., 2001. Palynostratigraphic zonation of the Tertiary sediments of the kerala basin India. Proceedings of the 9th International Palynological Congress, American Association of Stratigraphic Palynologist Foundation, Houston, Texas, USA., 277-289.

Rull, V., 2003. Botanical affinities and deduced environmental requirements of the taxa selected for numerical analysis. Palynology, 27: 75-98.

Sowumi, M. A., 1981. Aspects of Late Quartenaryvegetational changes in West Africa. Journal of Biogeography, 8:457-474.

Sowumi, M. A., 1987. Palynological Studies in the Niger Delta. In: the Early History of the Niger Delta. Alagoa, E.J., F.N. Anozie and N.Nzewunwa (Eds.) Elmat Busk Verlag Hamburg, 29-59.

Udeze, C. U and Oboh-lkuenobe, F. E., 2005. NeogenePaleoceanographic and Paleoclimatic events inferred from palynological data: Cape Basin off South Africa, ODP leg 175. Paleogeography, Paleoecology 219: 199-223.
Paleoclimatology 
Vermoere, M., Degryse, P., Vanecke, L., Muchez, P and

Panlissen, E. 1999. Pollen analysis of two travertine sections in Boskoy(southwestern Turkey): implications for environmental conditions during the Early Holocene. Review Paleobotany Palynology 105: 93-110.

Weber, K. J., 1987. Hydrocarbon distribution patterns in Nigerian growth fault structures controlled by structural style and stratigraphy: Journal of Petroleum Science and Engineering, 1, 91-104.
Whiteman, A., 1982. Nigeria: Its Petroleum Geology, Resources and Potential. Graham and Trotman, London. 382. 